\title{
INFLUENCE OF LIVE YEAST CULTURE ON MILK PRODUCTION, COMPOSITION AND SOME BLOOD METABOLITES OF OSSIMI EWES DURING THE MILKING PERIOD
}

Baiomy, A. A.

Animal Production Department, Faculty of Agriculture, South Valley University, Qena, Egypt.

\begin{abstract}
A feeding trial was conducted to evaluate the influence of live yeast culture (Saccharomyces cerevisiae) on milk production, composition, and some blood metabolites of Ossimi ewes during the milking period. The control group(G1) was fed a concentrate mixture (CFM) and hay $(\mathrm{H})$ and grazed twice daily, while the second group (G2) and third group (G3) were fed the same diet supplemented with 3 or $6 \mathrm{~g}$ of live yeast culture (Yea Sacc1026), respectively. The treated groups had significantly higher values $(p<0.05)$ for fat corrected milk (FCM) $(740,605,571 \mathrm{~g} /$ day, for G3, G2 and G1 vs, respectively), while the values for milk yield, fat yield and lactose yield were higher $(p<0.05)$ only in $G 3$ compared with $\mathrm{G} 1$. Milk yield values were constantly higher in G3 than in G1 while the values for the G3 were more variable during milking. Milk composition was not significantly affected by yeast supplementation with the exception of urea values which were significantly $(p<0.05)$ lower in G3. Yeast administration influenced $\beta$-hydroxy-butyrate $(\mathrm{BHB})$ values, which were significantly $(p<0.05)$ higher in the treated groups; and non-esterified fatty acids (NEFA) values, which were significantly $(p<0.05)$ higher only in the G3 compared with the G1. Other blood metabolites values were not influenced by the treatments. It was concluded that supplementation with live yeast culture, under the conditions of this experiment, had a significant effect on the performance and metabolism of Ossimi ewes during the milking period. Based on more constant results, it is recommend to include live yeast culture (Yea Sacc1026) at 6g/animal/day as appropriate level for field conditions.

Keywords : live yeast culture, metabolic profile, ewes, milking.
\end{abstract}

\section{INTRODUCTION}

Sheep milk is uniquely different from cow or goat milk. Sheep milk has about twice the fat of cow milk and $40 \%$ more protein than cow milk. In the last twenty years, some probiotics, such as Aspergillus or A. Niger (Pioneer, 1989), yeast culture (Saccharomyces cerevisiae) (Wallace,1994) and some microbial growth promoters e. g.thiamine ,niacin (Shields,1981) were used as feed additives in order to improve rumen conditions and cellulose digestion in the rumen and milk yield of dairy cows. Inactive dry yeast is only used to improve the yield and composition of milk in sheep and also as a source of protein and vitamins of B-complex, when added to rations (Dilanyan et al. 1974 and Peppler 1979). Products containing Saccharomyces cerevisiae vary widely in efficiency, primarily because of differences in strain and the viability of yeast cells. Numerous models have been designed to explain the effects of yeast in the rumen. Data indicate that supplementation of yeast in the ruminant diet may improve feed intake (Williams et al.1991 and Robinson and Garrett 1999), milk production (Wang 
et al. 2001 and Abd El-Ghani 2004), weight gain (Salama et al. 2002), digestion (Wohlt et al.1991 and Jouany et al.1998), numbers of anaerobic and cellulolytic bacteria (Newbold et al.1995), ruminal pH value (Doreau and Jouany 1998;Jouany et al.1998), and alter the patterns of volatile fatty acids (Arcos-Garcia et al.2000) or even supply the animal with unknown growth factors (Girard and Dawson 1995). Nevertheless, the results of these studies have been variable and strongly influenced by ration composition (Dawson 1992 and Newbold 1996). The influence of yeast supplementation on grazing animals has mainly been investigated in grazing steers (Olson et al.1994a,1994b and Arakaki et al. 2000). Much less is known about the effects of yeast supplementation on grazing dairy ewes, nevertheless in vitro trials (El Hassan et al.1994) and trials on grazing steers may give justification for more investigation.

\section{MATERIALS AND METHODS}

The live yeast culture supplements: (Saccharomyces cerevisiae)

(Yea Sacc 1026 ; Alltech, Inc., Nicholasville, Kentucky, USA)

\section{Feeding and management:}

The present study was carried out at the Experimental farm of Animal Production Department, Faculty of Agriculture, South Valley University, Qena during the period from February to July 2010. A feeding trial was conducted to evaluate the influence of live yeast culture (Saccharomyces cerevisiae) on milk production, composition, and blood metabolites of Ossimi ewes during the milking period. Sixty Ossimi ewes (aged 3-3.5 years, average body weight $48.3 \pm 3.13 \mathrm{~kg}$ ) were used in the lactation trial from the $42^{\text {th }}$ to the 182 th day of lactation, which is the usual period of milking in the region. All ewes were in second lactation. The sheep were divided into three groups on the 42 th day of lactation after peak to carry out the experiment. The sixty Ossimi ewes at peak of lactation (42day) were divided into three groups (20animals/each): Control group(G1): received only $100 \%$ of NRC (2001) nutrient allowances of dairy sheep without live yeast culture for 6 weeks after parturition, G2: received $100 \%$ of NRC nutrient allowances of dairy sheep (2001) with $3 \mathrm{~g} /$ day/sheep of live yeast culture for 6 weeks after parturition and G3: received $100 \%$ of NRC nutrient allowances of dairy sheep (2001) with $6 \mathrm{~g} /$ day/sheep of live yeast culture for 6 weeks after parturition.

Animals were kept in open yards belonging to Animal Production Experimental Farm, Faculty of Agriculture, South Valley University. During the experimental period the animals received $1 \mathrm{~kg} / \mathrm{ewe} /$ day of concentrate mixture, $0.3 \mathrm{~kg} / \mathrm{ewe} / \mathrm{day}$ rice straw and were allowed to graze (mixed grass pasture and alfalfa hay) from 7.00a.m and 3.00p.m. Animals were fed(at $7.00 \mathrm{a} . \mathrm{m}$ and $5.00 \mathrm{p} . \mathrm{m})$ ration consisted of a concentrate mixture according to their live body weight and level of milk production. Beside the concentrate mixture, animals were fed mixed grass pasture(natural pasture, cereal stubble, crop residue, vegetable by-products )and alfalfa hay. Water was available all day and minerals were supplied in salt licking blocks. Animals were adopted the double daily milking at $6.0 \mathrm{a} . \mathrm{m}$. and 5.00 p.m. The daily control ration consisted of concentrate mixture: $36.5 \%$ yellow maize, 
$16 \%$ wheat bran, $16 \%$ sunflower meal, $8 \%$ soybean meal, $20 \%$ barley meal, $2 \%$ calcium carbonate and $1 \%$ sodium chloride, and $0.5 \%$ mineral and vitamins additives. The rations were fed to ewes as Total Mixed Rations, based on NRC (2001). The Total Mixed Rations comprised of $65 \%$ forage and $35 \%$ of a concentrate mix to formulate diets to meet NRC (2001). Approximate and analysis of the concentrate mixture, mixed grass pasture and alfalfa hay are provided in Tables (1 and 2) according to AOAC(1995) Body weight of animals was recorded at the beginning and at the end of the experiment.

Table (1): Formulation of the concentrate mixture diet .

\begin{tabular}{|l|c|}
\hline \multicolumn{1}{|c|}{ Ingredients } & Concentrate mixture \\
\hline Soybean meal & $8 \%$ \\
\hline Yellow maize & $36.5 \%$ \\
\hline sunflower meal & $16 \%$ \\
\hline Barley meal & $20 \%$ \\
\hline Wheat bran & $16 \%$ \\
\hline Calcium carbonate & $2 \%$ \\
\hline Sodium chloride & $1 \%$ \\
\hline Vitamin-mineral mixture & $0.5 \%$ \\
\hline Total & 100.0 \\
\hline
\end{tabular}

Table (2): Composition and chemical analysis of experimental basal diet of rations.

\begin{tabular}{|l|c|c|c|}
\hline $\begin{array}{c}\text { Chemical composition } \\
(\%):\end{array}$ & $\begin{array}{c}\text { Concentrate } \\
\text { mixture }\end{array}$ & $\begin{array}{c}\text { Mixed grass } \\
\text { pasture }\end{array}$ & Alfalfa hay \\
\hline Dry matter & 88 & 21 & 89 \\
\hline Ash & 7.5 & 8.1 & 7.2 \\
\hline Crude fat & 3.0 & 3.8 & 2.3 \\
\hline Crude protein & 17.3 & 11.2 & 15.9 \\
\hline Crude fibre & 9.7 & 33.5 & 33.2 \\
\hline Neutral detergent Fibre & 16.9 & 59.5 & 52.3 \\
\hline Acid detergent fibre & 7.1 & 36.4 & 38.6 \\
\hline Calcium & 0.66 & 0.38 & 1.28 \\
\hline Phosphorus & 0.78 & 0.30 & 0.29 \\
\hline Magnesium & 0.24 & 0.14 & 0.30 \\
\hline Sodium & 0.23 & 0.19 & 0.12 \\
\hline Sulphur & 0.05 & 0.15 & 0.24 \\
\hline Potassium & 0.81 & 1.68 & 1.9 \\
\hline Chloride & 0.08 & 0.57 & 0.37 \\
\hline Zinc (mg-kg-1) & 96 & 2822 & 22 \\
\hline Manganese $(\mathrm{mg} \cdot \mathrm{kg}-1)$ & 75 & 8966 & 66 \\
\hline
\end{tabular}

\section{3-Samples collection and measurement :}

\section{Feed samples:}

Samples of the concentrate, hay and pasture were collected throughout the experimental period for chemical composition analyses. The samples were ground and analyses were made according to the AOAC (1999). Neutral Detergent Fibre (NDF) and Acid Detergent Fibre (ADF) were 
determined by detergent procedure of Robertson and Van Soest (1981) and Van Soest et al. (1991), with alpha amylase (SIGMA-ALDRICH, Inc., USA) being added during NDF extraction. Sodium sulphite was not added. Feed samples were dried to ashed at $600^{\circ} \mathrm{C} / 6 \mathrm{hrs}$. then after Calcium, Sodium, Potassium, Chloride, Magnesium, Sulphur, Zinc and Manganese concentrations were measured by using PV9100 atomic absorption spectrophotometer and they were analyzed for Phosphorus by using Varian DMS 1005 UV Visible Spectrophotometer (A.O.A.C, 1990).

Milk and Blood samples:

Individual milk samples, consisted of proportional volumes of morning and evening milk, were collected in order to evaluate milk composition (5 $\mathrm{ml} / \mathrm{kg}$ of produced milk). A composed milk sample of each ewe was analyzed weekly. Fat percentage was determined by the standard Gerber method according to the British Standard Institute (1962). Protein percentage of milk was evaluated by Micro Kjeldahl technique (A.O.A.C, 1999). Total solids (TS) percentage of milk was determined gravimetrically using the method by Oser (1965). Solid not fat (SNF) was calculated by the difference (T.S\%-fat\%). Milk yield was corrected to $7 \%$ fat (Raafat and Saleh 1962). $7 \%$ FCM $=0.265 \times$ milk yield $(\mathrm{kg})+10.5 \times$ fat yield $(\mathrm{kg})$. The urea values were determined by an enzymatic colorimetric method using commercial kits of reagents (Patton and Grouch 1977). Somatic cell counts (SCC) was determined with by the citoflow method, using the instrument Foosomatic 90. pH : It was determined by using a $\mathrm{pH}$ meter combined with a glass electrode (Model SS-3, Beckman, Fullerton, CA, USA

Blood samples were collected on the $42^{\text {th }}, 112^{\text {th }}$ and $182^{\text {th }}$ day of lactation by puncture of the jugular vein, with the addition of heparin as an anticoagulant, prior to morning feeding. Blood was allowed to coagulate at room temperature. The blood plasma was separated by centrifugation and stored at $-20^{\circ} \mathrm{C}$ for a maximum of 60 days until assayed. Obtained blood serum were subjected to determine blood plasma constituents as described by Wiebe and Bernert (1984), Kaplan and Szalbo (1983) , Doumas(1971) and Trinder (1969).

4- Statistical analysis of the data :

Data were statistically analyzed according to the General Linear Model G.L.M) by using SAS (1998) and the differences among means were detected by Duncan`s Multiple Range Test (Duncan , 1955).

\section{RESULTS}

The values for milk yield and composition are presented in Table 3 . Supplementation with live yeast culture only significantly $(p<0.05)$ increased the total milk yield during the experimental period in G3 although G2 also had a higher values, but non-significantly, milk yield than the control group. Values for FCM were higher in the treated groups and the differences were significant $(\mathrm{p}<0.05)$ than in $\mathrm{G} 1$ (control). Fat yield and lactose yield significantly $(p<0.05)$ increased only in $G 3$ compared to G1. The chemical composition of the milk was not influenced by the treatments with the exception of milk urea nitrogen which was significantly $(p<0.05)$ lower in the $G 3$, the differences were significant. Values of milk yield and chemical composition did not differ 
from the respective values recorded in other animals in the herd (not included in the experiment) kept on the experimental farm. The values of blood biochemistry are summarised in Table 4 . Values for $\beta$-hydroxy-butyrate $(B H B)$ were significantly $(p<0.05)$ higher in the treated groups than in the $G 1$ group and non-esterified fatty acids (NEFA) values were significantly $(p<0.05)$ higher in G3 than in the control group. All other values concerning blood components were not significantly different among other groups.

Table (3): Means \pm SE for milk yield and composition of Ossimi ewes as affected by yeast supplementation in the ration .

\begin{tabular}{|l|c|c|c|}
\hline \multirow{2}{*}{ Composition of milk } & G1 & G2 & G3 \\
\cline { 2 - 4 } & $\begin{array}{c}\text { Og of live yeast } \\
\text { culture per day }\end{array}$ & $\begin{array}{c}\text { 3g of live yeast } \\
\text { culture per day }\end{array}$ & $\begin{array}{c}\text { 6g of live yeast } \\
\text { culture per day }\end{array}$ \\
\hline NO & 20 & 20 & 20 \\
\hline Milk yield (g/day) & $527 \pm 55 \mathrm{~b}$ & $564 \pm 53 \mathrm{ab}$ & $670 \pm 76 \mathrm{a}$ \\
\hline Fat $(\%)$ & $7.8 \pm 0.3$ & $7.7 \pm 0.3$ & $8.0 \pm 0.1$ \\
\hline Protein (\%) & $5.8 \pm 0.47$ & $5.7 \pm 0.35$ & $5.7 \pm 0.51$ \\
\hline Lactose (\%) & $4.4 \pm 0.1$ & $4.4 \pm 0.2$ & $4.3 \pm 0.2$ \\
\hline Total solids (\%) & $19.0 \pm 0.8$ & $18.8 \pm 0.5$ & $19.5 \pm 0.8$ \\
\hline Non-fat solids (\%) & $11.2 \pm 0.4$ & $11.0 \pm 0.3$ & $11.1 \pm 0.6$ \\
\hline FCM7(g/day) & $571.62 \pm 63 \mathrm{~b}$ & $605.48 \pm 73 \mathrm{a}$ & $740.35 \pm 81 \mathrm{a}$ \\
\hline Fat yield (g/day) & $73 \pm 8 \mathrm{~b}$ & $76 \pm 8 \mathrm{~b}$ & $85 \pm 15 \mathrm{a}$ \\
\hline Protein yield (g/day) & $54 \pm 5$ & $56 \pm 6$ & $60 \pm 8$ \\
\hline Lactose yield (g/day) & $38 \pm 5 \mathrm{~b}$ & $43 \pm 3 \mathrm{ab}$ & $47 \pm 8 \mathrm{a}$ \\
\hline SCC (X 103/ml) & $405 \pm 169$ & $380 \pm 75$ & $490 \pm 15.2$ \\
\hline Urea N (mg/100ml) & $27.4 \pm 2.46 \mathrm{a}$ & $27.16 \pm 1.95 \mathrm{a}$ & $25.01 \pm 2.55 \mathrm{~b}$ \\
\hline Ph & $6.76 \pm 0.44 \mathrm{a}$ & $6.72 \pm 0.36 \mathrm{a}$ & $6.74 \pm 0.43 \mathrm{a}$ \\
\hline
\end{tabular}

a and means in the same row followed by different letters are significantly different $(p<0.05)$.

* FCM7\% = fat corrected milk (7\% milk fat);

Table (4): Means $\pm S E$ for blood plasma constitunits of sheep groups fed on different levels of live yeast culture.

\begin{tabular}{|c|c|c|c|}
\hline \multirow{2}{*}{ Biochemical indicators } & G1 & G2 & G3 \\
\hline & $\begin{array}{l}0 \mathrm{~g} \text { of live yeast } \\
\text { culture per day }\end{array}$ & $\begin{array}{l}3 \mathrm{~g} \text { of live yeast } \\
\text { culture per day }\end{array}$ & $\begin{array}{l}6 \text { of live yeast } \\
\text { culture per day }\end{array}$ \\
\hline $\mathrm{NO}$ & 20 & 20 & 20 \\
\hline $\operatorname{NEFA}\left(\mathrm{mmol}^{-1} 1\right)^{*}$ & $0.30 \pm 0.10 \mathrm{~b}$ & $0.37 \pm 0.20 a b$ & $0.38 \pm 0.12 a$ \\
\hline $\mathrm{BHB}\left(\mathrm{mmol}^{-1} \mathrm{l}\right)$ & $0.51 \pm 0.08 b$ & $0.61 \pm 0.14 a$ & $0.60 \pm 0.12 a$ \\
\hline Urea (mmoll'1) & $7.40 \pm 1.39$ & $7.31 \pm 0.86$ & $6.94 \pm 1.17$ \\
\hline Triglycerides $\left(\mathrm{mmol}^{\prime} \mathrm{l}^{-1} 1\right)$ & $0.25 \pm 0.06$ & $0.24 \pm 0.06$ & $0.28 \pm 0.07$ \\
\hline Cholesterol (mmol'l'1) & $1.92 \pm 0.23$ & $1.91 \pm 0.25$ & $1.96 \pm 0.16$ \\
\hline VLDL (\%) & $6.3 \pm 4.1$ & $6.1 \pm 4.0$ & $7.7 \pm 4.0$ \\
\hline HDL (\%) & $44.5 \pm 12.1$ & $46.6 \pm 8.7$ & $48.5 \pm 8.8$ \\
\hline LDL (\%) & $49.1 \pm 12.6$ & $47.2 \pm 7.9$ & $43.7 \pm 10.0$ \\
\hline AST ( $\mu$ kat l-1) & $2.55 \pm 1.01$ & $2.78 \pm 1.30$ & $2.45 \pm 0.95$ \\
\hline ALT $\left(\mu\right.$ kat $\left.^{\circ} 1\right)$ & $0.31 \pm 0.15$ & $0.23 \pm 0.12$ & $0.26 \pm 0.13$ \\
\hline GGT $\left(\mu \mathrm{kat}^{\top} \mathrm{I}^{-1} 1\right)$ & $0.82 \pm 0.07$ & $1.07 \pm 0.20$ & $0.93 \pm 0.33$ \\
\hline ALP ( $\mu$ kat l'1) & $3.82 \pm 0.98$ & $3.75 \pm 1.43$ & $3.28 \pm 1.30$ \\
\hline
\end{tabular}


Baiomy, A. A.

\section{DISCUSSION}

In this study, the live yeast culture included the ewes' diet showed a positive effect on milk yield during lactation. This has also been reported in dairy cows (Wohlt et al.1991 and Robinson and Garrett 1999 and Wang et al. 2001), also the same trend in dairy goats was observed by (Reklewska et al. 2000 and Abd El-Ghani 2004 and Stella et al. 2007). In contrast, other authors found no improvement of milk yield in dairy cows (Arambel and Kent 1990 ; Swartz et al. 1994 and Soder and Holden 1999), dairy goats (Hadjipanayiotou et al. 1997; Giger-Reverdin et al. 1996) or in dairy ewes (Hadjipanayiotou et al. 1997). These results reflect that the effects of live yeast culture.

Administration were strongly influenced by diet composition. Although many authors stated that live yeast cultures are most efficient when animals are fed diets poor in nutrient supply (Plata et al.1994 and Jouany et al. 1998 ) or high concentrate diets overloaded with energy (Williams et al. 1991 and Zelenak et al. 1994), in some cases it is difficult to find a correlation between diet composition and the results of yeast supplementation. The animals in the present were fed relatively high levels of concentrate $(1 \mathrm{~kg} / \mathrm{animal} / \mathrm{day})$ which could lead to improved buffering capacity in the rumen. the results were also dose-dependent because $3 \mathrm{~g}$ of live yeast cultures per day was not efficient enough to maintain a constantly higher milk yield than in the control group. Similar results were obtained by Abd El-Ghani (2004) with 3 and $6 \mathrm{~g}$ of live yeast cultures per day fed to dairy goats. Due to the higher amount of total solids in sheep milk, compared to cows and goats, it is expected that the supplementation of yeast may be more efficient in changing milk composition. However, the milk fat content was not significantly higher in the treated groups than in the control group, which is in agreement with Piva et al. (1993) who stated that the common result of yeast supplementation to dairy cows is only a slight (nonsignificant) increase in the milk fat content. Hadjipanayiotou et al. (1997) and Stella et al. (2007) also reported no increase in milk fat content in dairy goats. In Damascus dairy ewes Hadjipanayiotou et al. (1997) found no influence of live yeast administration on milk composition, although in their study the yeast was steam-pelleted with no report on cell viability. On the contrary, Giger-Reverdin et al. (1996), Abd El-Ghani (2004) and Masek et al. (2008) found increased milk fat values in dairy goats and ewes. Milk protein and lactose values did not differ between the treatments, which was also noticed by the majority of authors (Stella et al. 2007; Giger-Reverdin et al. 1996). Milk urea values were significantly ( $p>0.05)$ lower in the group fed 6 $\mathrm{g}$ per day. Harrison et al. (1988) reported a much lower concentration of rumen ammonia $\mathrm{N}$ after yeast supplementation, which is in agreement with the results of Erasmus et al. (1992), who found that the mean concentration of rumen ammonia decreased by $10 \%$ after live yeast culture supplementation. Erasmus et al. (1992) explained these reduced concentrations of ammonia in the rumen as the result of increased incorporation of ammonia into microbial protein stimulated microbial activity which could explain lower blood and milk urea values the present experiment. Results significantly subsequent showed $(p<0.05)$ higher non- 
esterified fatty acids (NEFA) and $\beta$-hydroxy-butyrate (BHB) values were presently recorded in the treated groups, which is in agreement with GigerReverdin et al. (1996) and Quigley et al. (1992). Increase in non-esterified fatty acids (NEFA) values could be explained by increased mobilisation of fat tissue caused by live yeast supplementation, which was also noted in dairy goats (Giger-Reverdin et al. 1996). According to Quigley et al. (1992), the increased ruminal butyrate was at least partially responsible for increased $\mathrm{BHB}$ values. Triglycerides and cholesterol values tended to be higher in the treated groups, which was also noted by Pysera and Opalka (2001). The same authors also found, in contrast to our results. All metabolites values were within the normal reference range for lactating dairy ewes (Dubreuil et al. 2005; Roubies et al. 2006; Yokus and Cakir 2006 and Masek et al. 2007). Literature dealing with yeast supplementation in grazing animals is scarce and to our knowledge, involves mainly steers. Various authors found an increased number of protozoa increased the live body weight gain (Arakaki et al. 2000), (Combellas et al. 2002) and increased degradation and digestibility (Olson et al. 1994a, 1994b). (Dawson 1992; Wallace and Newbold 1992; Newbold et al. 1995), showed that the micro-population plays a key role in the mode of action of yeast in the rumen El Hassan et al. (1994) dound that the Yea Sacc1026 stimulated the total bacterial number in a rumensimulating fermentor when the basal diet was grass and increased, the number of cellulolytic bacteria. Subsequent increased the degradalility and digestion then fore the better performance and best daily weight gain. I concluded that the supplementation of live yeast culture (Yea Sacc1026) had a significant beneficial effect on the milk yield of Ossimi sheep, fed pasture and concentrate mixture during the milking period. The significant results were probably a result of the interactions between yeast culture supplementation and diet composition. Since the influence was dosedependent, we could recommend $6 \mathrm{~g}$ per day for inclusion in dairy sheep diets. Additional studies under different feeding conditions and in earlier stages of lactation should clarify the influence of live yeast supplementation in the diets of Ossimi ewes and define the dietary situations in which it may be beneficial.

It could be concluded that the supplementation of live yeast culture (Yea Sacc1026) had a significant beneficial effect on the milk yield of Ossimi sheep, fed pasture and concentrate mixture during the milking period. The significant results were probably a result of the interactions between yeast culture supplementation and diet composition. Since the influence was dosedependent, $6 \mathrm{~g}$ per day for inclusion in dairy sheep diets, is recommended . Additional studies under different feeding conditions and in earlier stages of lactation should clarify the influence of live yeast supplementation in the diets of Ossimi ewes and define the dietary situations in which it may be beneficial. 


\section{REFERENCES}

Abd El-Ghani, A. A. (2004). Influence of diet supplementation with yeast culture (Saccharomyces cerevisiae) on performance of Zaraibi goats. Small Ruminant Res., 52: 223-229.

AOAC (1990). Menrals in Animal Feed. Assosiation of Official Analytical Chemistry Vol: 1 Arlington, Virginia 85202201 U.S.A.

AOAC (1995). Association of Official Agriculture Chemists. Official Methods of Analysis. 10 th Ed. Published by the AOAC, Washington, D. C., USA .

AOAC (1999). Association of Official Analytical Chemists. Official Methods of Analysis, 16th ed. AOAC International Gaithersburg, MD., p. 111.

Arakaki, L.C. ; R.C. Stahringer ; J.E. Garrett and B.A. Dehority (2000). The effects of feeding monensin and yeast culture, alone or in combination, on the concentration and generic composition of rumen protozoa in steers fed on low-quality pasture supplemented with increasing levels of concentrate. Anim. Feed Sci. Technol., 84: 121-127.

Arambel, M.J. and B.A. Kent (1990). Effect of yeast culture on nutrient digestibility and milk yield response in early to midlactation dairy cows.J. Dairy Sci., 73: 1560-1563.

Arcos-Garcia, J.L. ;F.A. Castrejon ;G.D. Mendoza and E.P. Perez-Gavilan (2000). Effects of two commercial yeast cultures with Saccharomyces cerevisiae on ruminal fermentation and digestion in sheep fed sugar cane tops. Livest Prod. Sci., 63: 153-157.

British Standards Institution(1962).British Standard methods for dertermination of milk fat the Gerber method. bull, P. 962.

Combellas, J. ; S. Jacqueline ;M. Tesorero and L. Gabaldonl (2002). Response of yearling cattle to the addition of yeast culture to a diet of pasture, poultry litter and wheat middlings. Zootec Trop., 20: 373-381.

Dawson, K.A. (1992). Current and future role of yeast culture in animal production: A review of research over the past six years. In: LYONS TP (Ed.): Proceedings of Alltech's 8th annual symposium, Nicholasville, Kentucky, pp., 1-23.

Dilanyan, Z. KH.; R.V. Sarkisyan; A.S. Sagoyan; D.F. Chuprina and R.A. Amirkhanyan. (1977). Effect of x-ray induced mutants and certain stimulants on fermentation processes in milk manufacture. Dairy Sci. Abstr., 37(8):5000.

Doreau, M and J.P. Jouany (1998). Effect of a Saccharomyces cerevisiae on nutrient digestion in lactating dairy cow. J. Dairy Sci., 81:3214-3221.

Doumas, B. T (1971). Automated analysis. Bochringer Mannheim Clin. Acta., 31-87.

Dubreuil, P. ; J. Arsenault. and D. Belangerd (2005). Biochemical reference ranges for groups of ewes of different age. Vet. Rec., 156: 636-638.

Duncan, D.B. (1955). Multiple range and multiple F-test Biometrics, 11:1-42.

El Hassan, S.M.; C.J. Newbold and R.J. Wallace (1994). The effect of yeast culture addition to diets of grass and grass silage on rumen bacterial numbers. Anim. Prod., 58: 451. 
Erasmus, L.J. ; P.M. Botha and A.A. Kistner (1992). Effect of yeast culture supplement on production, rumen fermentation, and duodenal nitrogen flow in dairy cows. J. Dairy Sci., 75: 3056-3065.

Giger-Reverdin, S. ; N. Bezault ;D. Sauvant and G. Bertin (1996). Effects of a probiotic yeast in lactating ruminants: interaction with dietary nitrogen level. Anim. Feed Sci. Technol., 63: 149-162.

Girard, I.D. and K.A. Dawson (1995). Stimulation of ruminal bacteria by different fractions derived from cultures of Saccharomyces cerevisiae strain 1026. J. Anim. Sci., 73 (Suppl): 264.

Hadjipanayiotou, M.;I. Antoniou and A. Photiou (1997). Effects of the inclusion of yeast culture on the performance of dairy ewes and goats and the degradation of feedstuffs. Livest. Prod. Sci., 48: 129-134 .

Harrison, G.A.; R.W. Hemken ;K.A. Dawson ;R.J. Harmon and K.B. Barker (1988). Influence of addition of yeast culture supplement to diets of lactating cows on ruminal fermentation and microbial populations. J. Dairy Sci., 71: 2967-2975.

Jouany, J.P.; F.Mathieu ; J.Senaud ;J. Bohatier ;G. Bertin and M. Mercier (1998). The effect of Saccharomyces cerevisiae and Aspergilus oryzae on the digestion of the cell wall fraction of a mixed diet in defaunated and refaunated sheep rumen. Reprod. Nutr. Dev., 38: 401-416.

Kaplan, A. and J. Szalbo (1983). Clinical chemistry : interpretation and techniques. $2^{\text {nd }}$ ed. p157.

Masek, T.; Z. Mikulec ;H. Valpotic ;L. Kusce ; N. Mikulec and N. Antunac (2008). The influence of live yeast cells (Saccharomyces cerevisiae) on the performance of grazing dairy sheep in late lactation. Vet. Arh., 78: 95-104.

Masek, T.; Z. Mikulec ;H. Valpotic and S. Pahovic (2007). Blood biochemical parameters of crossbred Istrian $X$ East Friesian dairy ewes: relation to milking period. Ital. J. Anim. Sci., 6: 281-288.

Newbold, C.J. (1996). Probiotics for ruminants. Ann. Zootech., 45 (Suppl): 329-335.

Newbold, C.J.; R.J. Wallace ; X.B. Chen and F.M. Mcintosh (1995). Different strains of Saccharomyces cerevisiae differ in their effects on ruminal bacterial numbers in vitro and in sheep. J. Anim. Sci., 73: 1811-1818.

NRC (2001). Nutrient requirements of sheep. 6th rev. ed. Committee on Animal Nutrition, National Research Council, 112 p. (ISBN 0309035961)

Olson, K.C.; J.S. Caton ;D.R. Kirby and P.L. Norton (1994 ${ }^{\text {a }}$ ). Influence of yeast culture supplementation and advancing season on steers grazing mixed-grass prairie in the northern Great Plains: II. Ruminal fermentation, site of digestion, and microbial efficiency. J. Anim. Sci., 72: 2158-2170.

Olson, K.C.; J.S. Caton ;D.R. Kirby and P.L. Norton $\left(1994^{\text {b }}\right)$. Influence of yeast culture supplementation and advancing season on steers grazing mixed-grass prairie in the northern Great Plains: I. Dietary composition, intake, and in situ nutrient disappearance. J. Anim. Sci., 72: 2149-2157.

Oser , L.B. (1965). Howk's physiological chemistry , McGraw - Hill Book Co., New York and London, $14^{\text {th }}$ Ed . pp. 390-391. 
Baiomy, A. A.

Patton, C.J. and S.R. Crouch (1977). Anal. Chem., 49.464-469.

Peppler, H. J. (1979). Food yeasts. Vol. /// (Rose, A. and, J. S. Harrison, Ed.) Academic press, London.

Pioneer, H.I. (1989). Summary of overall effect of Probios brand microbial products on performance and health of incoming feedlot cattle. Pioneer Hibred International . Research Update (1989).

Piva G, Belladonna S, Fusconi G, Sicbaldi F (1993). Effects of yeast on dairy cow performance, ruminal fermentation, blood components, and milk manufacturing properties. J. Dairy Sci., 76: 2717-2722.

Plata, F.P.; G.D. Mendoza; M.J.R. Barcena-Gama and M.S. Gonzalez (1994). Effect of a yeast culture (Saccharomyces cerevisiae) on neutral detergent fiber digestion in steers fed oat straw based diets. Anim. Feed Sci. Technol., 49: 203-210.

Pysera, B. and A. Opalka (2001). Lipids and lipoproteins in blood serum of calves receiving Yea-Sacc1026 dietary supplement. J. Anim. Feed Sci., 10: 77-82.

Quigley, J.D.; L.B. Wallis; H.H. Dowlen and R.N. Heitmann (1992): Sodium bicarbonate and yeast culture effects on ruminal fermentation, growth, and intake in dairy calves. J. Dairy Sci., 75: 3531-3538.

Raafat, M.A. and M.S. Saleh (1962).Two formulas for conversion of cows and buffaloes milk of different fat percentage into milk standard fat percentage, proceeding of the $1^{\text {st }}$ Anim. Prod . conference at Minia, P"203".

Reklewska, B.; Z. Ryniewicz ;J. Krzyzewski ;A. Karaszewska ;M. Goralczyk K. Zdziarski ;T. Nalecz-Tarwacka and N. Strzalkowska (2000). Dietary manipulation of milk protein content in goats. Ann. Wars. Agric Univ. Anim. Sci., 35: 133-143.

Robinson, P.H. and J.E. Garrett(1999). Effect of yeast culture (Saccharomyces cerevisiae) on adaptation of cows to postpartum diets and on lactational performance. J. Anim. Sci., 77: 988-999.

Robertson, J.B. and P.J. Van Soest (1981). The detergent system of analysis and its application to human foods In: JAMES WPT, THEANDER $O$ (Eds.): The analysis of dietary fiber in food. Marcel Dekker, New York, pp. 123-158.

Roubies, N.; N. Panousis ;A. Fytianou ; P.D. Katsoulos ;N. Giadinis and H. Karatzias (2006). Effects of age and reproductive stage on certain serum biochemical parameters of Chios sheep under Greek rearing conditions. J. Vet. Med. A-Physiol. Pathol. Clin. Med., 53: 277-281.

Salama, A.A.K.; G. Caja ;D. Garin ;E. Albanell ;X. Sush and R. Casals(2002). Effects of adding a mixture of malate and yeast culture (Saccharomyces cerevisiae) on milk production of Murciano-Granadina dairy goats. Anim. Res.,51:295-303.

S.A.S. (1998). Statistical Analysis System User, Quide :Basis. SAS Inst .Inc Cary. NC .

Shields, D.R. (1981). The influence of niacin supplementation on growing ruminants and in vivo and in vitro rumen parameters, $\mathrm{Ph}$. D Thesis, Purdue University, W. Lafayette., USA. 
Soder, K.J. and L.A. Holden (1999). Dry matter intake and milk yield and composition of cows fed yeast prepartum and postpartum. J. Dairy. Sci., 82: 605-610.

Stella, A.V.;R. Paratte;L. Valnegri; G. Ciglino; G. Soncini; E. Chevaux ;V. Dell Orto and G. Savoini (2007). Effect of administration of live Saccharomyces cerevisiae on milk production, milk composition, blood metabolites, and faecal flora in early lactating dairy goats. Small Ruminant Res., 67: 7-13

Swartz, D.L.; L.D. Muller; G.W. Rogers and G.A. Varga (1994). Effect of yeast cultures on performance of lactating dairy cows: a field study. J. Dairy Sci.,77: 3073-3080.

Trinder, P.(1969). Test-composition, enzymatic determination of glucose. Ann. Clin. Biochem, 6:24.

Van Soest, P.J.; J.B. Robertson and B.A. Lewis(1991). Methods for dietary fiber, neutral detergent fiber and nonstarch polysaccharides in relation to animal nutrition. J. Dairy Sci., 74: 3583-3597.

Wallace, R.J. (1994). Ruminal microbiology, biotechnology, and ruminant nutrition: progress and problems .J.Anim. Sci., 72: 2992- 3003.

Wallace, R.J. and C.J. Newbold (1992). Probiotics for ruminants. In: FULLER R. (Ed.):Probiotics :The scientific basis. Chapman and Hall, London, pp.317-353.

Wang, Z.; M.L. Eastridge and X Qiu (2001). Effects of forage neutral detergent fiber and yeast culture on performance of cows during early lactation. J. Dairy Sci., 84: 204-212.

Wiebe, D.A. and J.T. Bernert (1984). Clin. Chem. 30:352.

Williams, P.E.; C.A. Tait ; G.M. Innes and C.J. Newbold (1991). Effects of the inclusion of yeast culture (Saccharomyces cerevisiae plus growth medium) in the diet of dairy cows on milk yield and forage degradation and fermentation patterns in the rumen of steers. J. Anim. Sci., 69: 3016-3026.

Wohlt, J.E.; A.D. Finkelstein and C.H. Chung (1991). Yeast culture to improve intake, nutrient digestibility and performance by dairy cattle during early lactation. J. Dairy Sci., 74: 1395-1400.

Yokus, B. and U.D. Cakir (2006). Seasonal and physiological variations in serum chemistry and mineral concentrations in cattle. Biol. Trace Elem. Res., 109: $255-266$.

Zelenak, .I; V.Jalc ; V. Kmet and P. Siroka (1994). Influence of diet and yeast supplement on in vitro ruminal characteristic. Anim. Feed Sci. Technol., 49: 211-221. 
Baiomy, A. A.

تآثير إضافة الخميرة الحية بالعليقة على أنتاج وتركيب اللبن وبعض مكونـات اللام

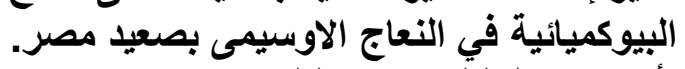

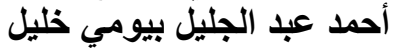
قسم الإتتاج الحيواني- كليّة الزراعة - جليل جامعة جنوب الوادي بقتا.

أجريت هذه الدراسة بمزرعة الإنتاج الحيو انيـ كلية الزراعة- جامعة جنوب الو ادي بقنا من

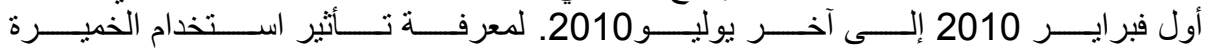

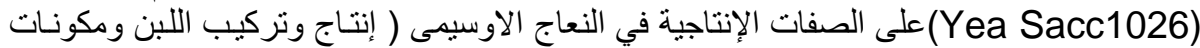

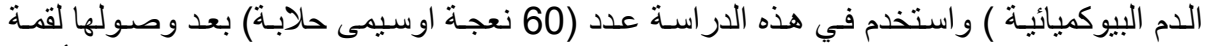

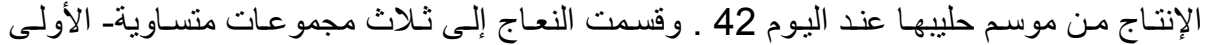

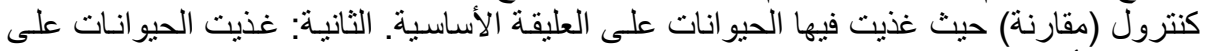

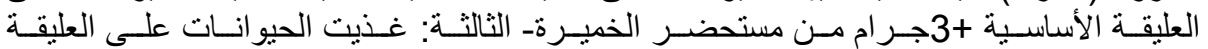

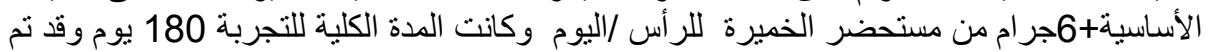

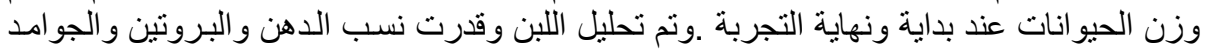

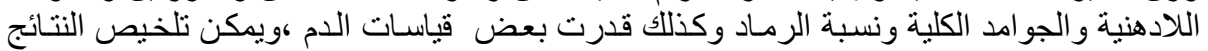

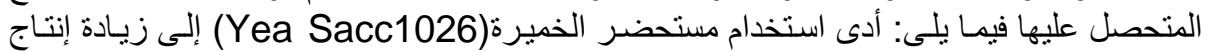

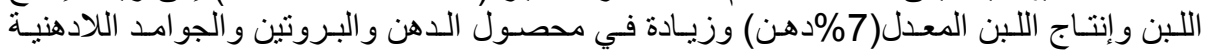

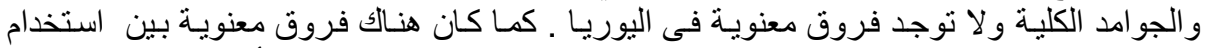

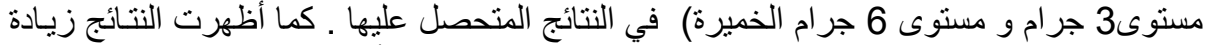

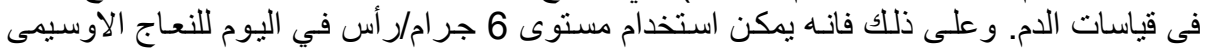

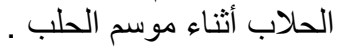

كلية الزراعة - جامعة المنصورة قام بتحكيم البحث مركز البحوث الزراعية

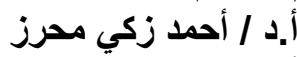

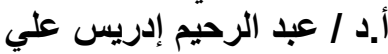

